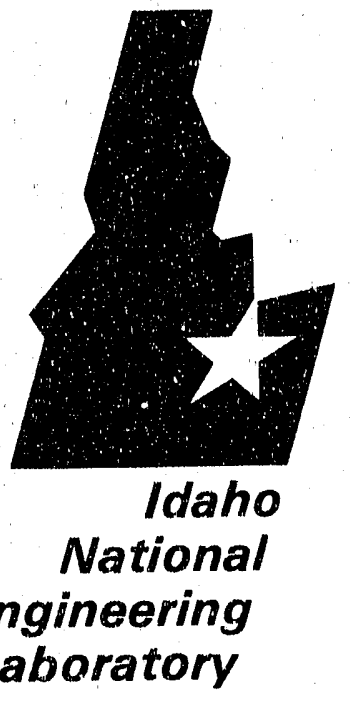

Managed

by the U.S.

Department

of Energy
EGG-GEO-9990

December 1991

APR2 9992

\section{INFORMAL REPORT}

AQUIFER TESTS NEAR THE IDAHO FALLS FOOTHILLS, IDAHO

Joel M. Hubbel1

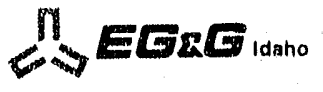

Work performed under
DOE Contract No. DE-AC07-761D01570 
EGG-GED- -9990

DE92 012237

\title{
AQUIFER TESTS NEAR THE IDAHO FALLS FOOTHILLS
}

\author{
J. M. Hubbel1 \\ Quantitative Hydrology Unit \\ Geosciences Group
}

October 3, 1991

\author{
Idaho National Engineering Laboratory \\ EG\&G Idaho, Inc. \\ Idaho Falls, Idaho 83415
}

Prepared for the

U.S. Department of Energy

Office of Environmental Restoration and Waste Management Under DOE Field Office, Idaho

Contract ACO7-76ID01570 
ABSTRAC

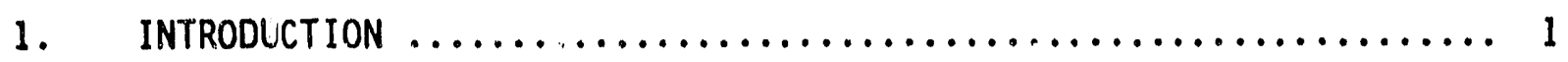

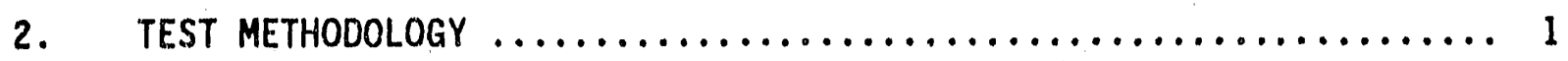

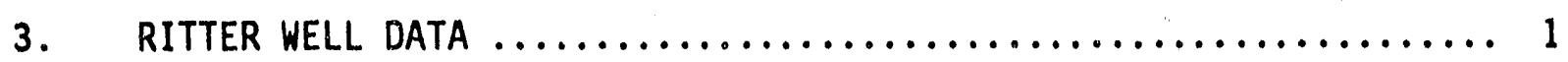

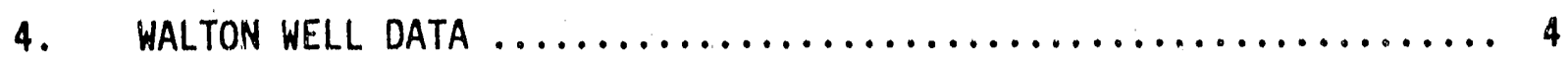

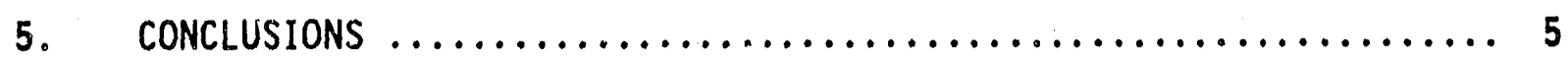

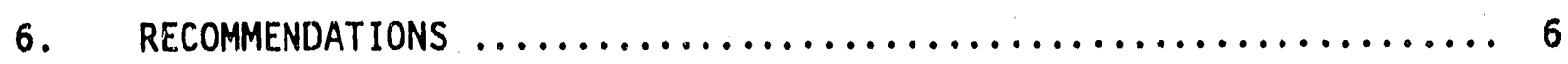

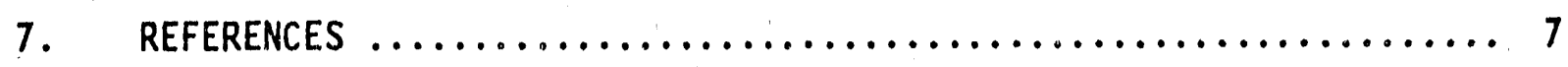

FIGURES

Page

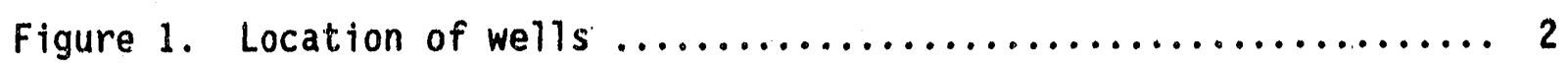

\section{APPENDICES}

Page

APPENDIX A- DRILLER'S LOGS............................. A-

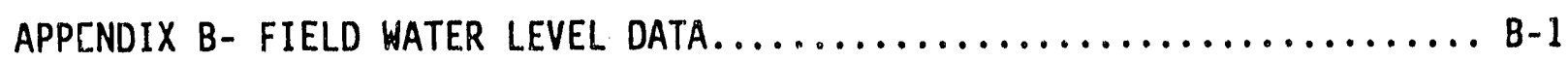




\section{AQUIFER TESTS NEAR THE IDAHO FALLS FOOTHILLS}

\section{ABSTRACT}

Ground water pumping tests were performed in two wells located in the foothills east of Idaho Falls to determine the aquifer characteristics at these locations. These data were used to differentiate this aquifer from the Snake River Plain aquifer. The wells were pumped at rates of 11 and 14 gallons per minute with 0.03 and $0.04 \mathrm{ft}$ of drawdown measured in the pumping wells. The transmissivity is estimated to be $525,000 \mathrm{gpd} / \mathrm{ft}$ and 450,000 $\mathrm{gpd} / \mathrm{ft}$, respectively. The hydraulic conductivity is $925 \mathrm{ft} /$ day and 1,070 $\mathrm{ft} /$ day, respectively. These hydraulic conductivities are similar to those measured in the Snake River Plain aquifer. Water level data in these wells are consistent with the water table in the Snake River Plain aquifer and indicates ground water movement from the foothills toward the Plain. The high transmissivity suggests water may move rapidly from the foothills area to mix with water in the Snake River Plain aquifer. Elevated water temperatures (76 and $70^{\circ} \mathrm{F}$ ) and high specific conductivities in these wells indicate the presence of a foothills aquifer with characteristics that can be used to seperate the two aquifer systems. 


\section{AQUIFER TESTS NEAR THE IDAHO FALLS FOOTHILLS}

\section{INTRODUCTION}

Pumping tests were performed at two wells in the foothills east of Idaho Falls to determine the aquifer characteristics in their respective areas. Locations of the test sites are presented in Figure 1 . Tests were performed at the Ritter well on August 14, 1991 and the Walton well on August 29, 1991. These we11s were chosen because they are close to areas being considered for the new Bonneville County landfill. The wells are located near the boundary of the Snake River Plain Aquifer and the foothills aquifer.

\section{TEST METHODOLOGY}

Single well pumping tests were performed in the we11s. Water level measurements were made in the well with a Solinst electric water level tape with gradations of $0.02 \mathrm{ft}$. Readings of $0.01 \mathrm{ft}$ can be estimated. Water level readings were recorded before, during, and after pumping. Pumping continued until the water level reached steady state conditions. Discharge was recorded by measuring the discharge in a calibrated measuring container for a given time period.

\section{RITTER WELL DATA}

The Ritter well is located in the NE $1 / 4$ of the NW 1/4 of Section 29, Township $2 \mathrm{~N}$, Range $39 \mathrm{E}$ in the foothills east of Idaho Falls at an approximate elevation of $5060 \mathrm{ft}$. The well was drilled in 1977 for Mike Watson. Static water table at the time of drilling was $365 \mathrm{ft}$ below land surface. Water level at the time of the pump test was $355 \mathrm{ft}$ below the top of the casing. Differences in water level suggest the water level has risen approximately nine feet since the well was drilled. Water ievel elevation is presently at approximately $4705 \mathrm{ft}$.

The Ritter well obtains water from what is interpreted as volcanic tuff (described as sandstone) and broken rhyolite (Appendix 1). Most of the water 


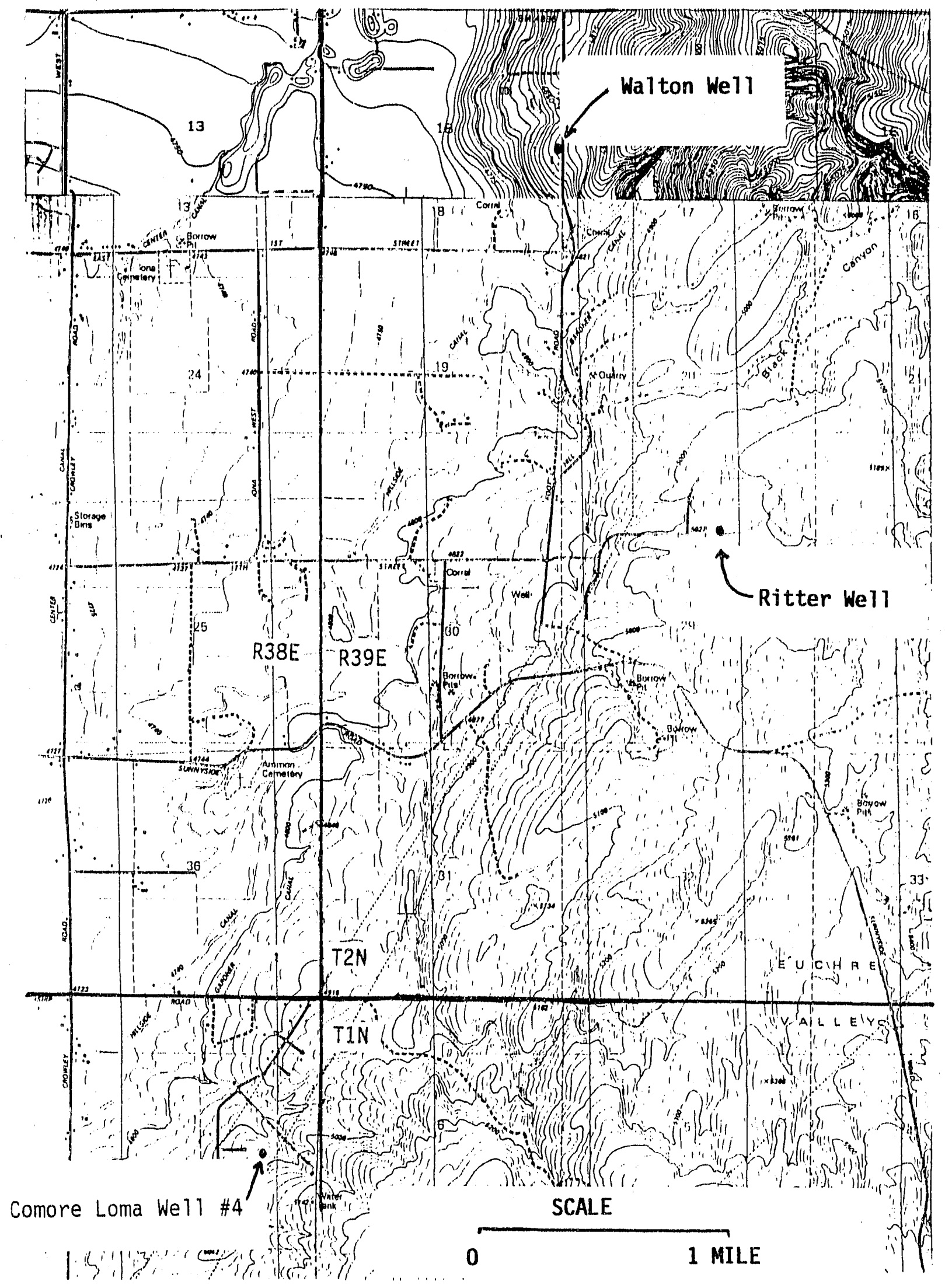

Figure 1. Location of wells. 
is probably obtained from fractured rhyolite. The well is uncased from 37 feet to the bottom of the well at $431 \mathrm{ft}$. Water level in the well is at 355 $\mathrm{ft}$, indicating $76 \mathrm{ft}$ of saturation.

Water was pumped from the well at a rate of 10 to 14 gallons per minute. The well had $0.04 \mathrm{ft}$ of drawdown during the test. All of the drawdown occurred in the first four minutes of the test, after which the water level did not change. This water level response precludes determination of transmissivity using classical methods based on the Theis analysis. Driscoll (1986) presents an empirical equation to estimate transmissivity:

$$
Q / s=T / 1500
$$

where $Q$ is discharge in gallons per minute (gpm), $s$ is drawdown in $\mathrm{ft}$, and $T$ is transmissivity in gallons per day per $\mathrm{ft}$. This well has a specific capacity of $350 \mathrm{gpm} / \mathrm{ft}$ and an estimate of transmissivity of $525,000 \mathrm{gpd} / \mathrm{ft}$. Dividing this by a $76 \mathrm{ft}$ saturated thickness gives an estimate of hydraulic conductivity of $6900 \mathrm{gpd} / \mathrm{ft}^{2}(925 \mathrm{ft} / \mathrm{day})$. These estimates are equivalent to those found in highly permeable basalts, karst limestones, clean sands, or gravel (Freeze and Cherry, 1979). The pumping water level in the well recovered to the original water level in $21 / 2$ minutes after the pump was turned off. The hydraulic conductivity from this pump test is similar to the value determined by the pump tesi on well Comore Loma \#4 (1300 ft/day).

Temperature and specific conductivity were measured in this well. The temperature of the water was $76^{\circ} \mathrm{F}$ (the well owners stated the water temperature has been measured as high as $80^{\circ} \mathrm{F}$ after extended pumping). The temperature is elevated above those measured in the Snake River Plain Aquifer and is similar to, but higher than measurements obtained from the Comore Loma \#4 well $\left(71^{\circ} \mathrm{F}\right)$. The specific conductivity was measured as 860 micromohs. This is similar to, but also higher than measurements from the Comore Loma well \#4 (800 micromhos). The hydraulic, temperature, and chemical properties measured in the Ritter well are similar to those measured in the Comore Loma Well \#4, tested previously. This infers the hydrologic conditions are similar between the sites, and the two wells may obtain water from the same aquifer. 


\section{WALTON WELL DATA}

The Walton well is located in the NE $1 / 4$ of the SE $1 / 4$ of Section 18 , Township 2, Range 39 in Bonneville County (Figure 1). This well is located one and $3 / 4$ miles northwest of the Ritter well. This well is located closer to the Snake River Plain aquifer than the Ritter or Comore Loma \#4 well and is at an elevation of $4860 \mathrm{ft}, 200 \mathrm{ft}$ lower than the Ritter well.

The well was drilled for Harold Lund in 1975. The depth to water is 167 $\mathrm{ft}$ below land surface. The water level was recorded at a depth of $164 \mathrm{ft}$ below land surface at the time of drilling. Since the casing is located approximately one foot below land surface, this indicates the water level has dropped three to four feet since the well was drilled.

The water level elevation is approximately $4693 \mathrm{ft}$, about $12 \mathrm{ft}$ lower than the water table in the Ritter well. Since ground water flow in the Snake River Plain aquifer is generally toward the southeast, the water level in wells in the Plain near the Ritter's well would be anticipated to be lower than in the Walton we11. The hydraulic gradient near this site is estimated to be $20 \mathrm{ft}$ per mile (Mundorff et. a1. 1964). Projecting this gradient to this site suggests an approximate $20 \mathrm{ft}$ head difference between the Ritter's well and a well in the Snake River Plain aquifer. This indicates the direction of ground water flow is from the foothills toward the Plain. Since, the elevations are taken off of topographic maps these measurements are only estimates, accurate to about $10 \mathrm{ft}$.

Water is obtained from pumice that underlies alternating layers of basalt and cinders. The well is uncased from $170 \mathrm{ft}$ to the bottom of the well at $220 \mathrm{ft}$. The water level in the well is at a depth of $167 \mathrm{ft}$, indicating 56 $\mathrm{ft}$ of saturation.

Water was pumped from the well at a rate of nine to 11 gallons per minute. The well had a total of $0.03 \mathrm{ft}$ of drawdown during the test. All of the drawdown occurred in the first half minute of the test and after which the water level stayed constant. This water level response precludes 
determination of transmissivity using classical methods based on the Theis analysis. The equation listed above was used to estimate a transmissivity of $450,000 \mathrm{gpd} / \mathrm{ft}$ using the calculated specific capacity of $300 \mathrm{gpm} / \mathrm{ft}$. Dividing this by a $56 \mathrm{ft}$ saturated thickness gives an estimate of the hydrautic conductivity of $8000 \mathrm{gpd} / \mathrm{ft}^{2}(1070 \mathrm{ft} /$ day $)$. The hydraulic conductivity of the Walton well is very close to values obtained from Comore Loma \#4 and the Ritter we11. These estimates are equivalent to those found in highiy permeable basalts, karst 1 imestones, and clean sands or gravel (Freeze and Cherry, 1979). The water level in the well recovered in two and a half minutes to the original water level following pump shutoff.

The temperature of the water was $70^{\circ} \mathrm{F}$ during the pumping test. The temperature is elevated above those measured in the Snake River Plain aquifer and is similar to measurements obtained from the Comore Loma \#4 we11 $\left(71^{\circ} \mathrm{F}\right)$. The specific conductivity was measured as 580 micromohs. This is significantly lower than values measured in the Comore Loma well \#4 or the Ritter well (800 and 860 micromhos, respectively).

\section{CONCLUSIONS}

Single well pumping tests were performed in two wells in the foothills east of Idaho Falls, near the proposed sanitary landfill locations. Results from pumping tests indicate these wells have high hydraulic conductivities of approximately $1000 \mathrm{ft} /$ day. The high hydraulic conductivities from the tests are comparable to those measured in the Snake River Plain aquifer. Water level data in these wells are consistent with the water table in the Snake River Plain aquifer and indicates ground water movement from the foothills toward the Plain. The high transmissivity suggests that water may move rapidly from the foothills area to mix with water in the Snake River Plain aquifer. Elevated water temperatures and high specific conductivities in these wells suggest the presence of a foothills aquifer that has distinguishable characteristics that could be used to separate the aquifers. 


\section{RECOMMENDATIONS}

Elevated temperatures and higher specific conductivity in wells in the foothills east of Idaho Falls suggest a distinguishable aquifer system that extends from the Thunder Ridge area through Rim Rock to the Comore Loma subdivision. This area should be characterized to determine the boundary of the Srake River Plain Aquifer in this region. This can be done by examining the geology, hydrology and geochemical characteristics of wells in this area. Static water level measurements combined with well elevation surveys could be used to determine ground water flow directions and the hydraulic gradients in this region. Temperature and chemical data would help delineate the location of the boundary of the Snake River Plain aquifer and the foothills aquifer. 


\section{REFERENCES}

1. Freeze R. A. and J. A. Cherry, 1979. Groundwater, Prentice-Ha11, Inc., Englewood Cliffs, New Jersey, 604 pp.

2. Mundorff, M. J., E. C. Crosthwaite, and C. Kilburn, 1964. Groundwater for Irrigation in the Snake River Basin in Idaho, U.S.Geological Survey Water-Supply Paper 1654, $244 \mathrm{np}$. 
APPENDIX A
DRILLER'S LOGS 


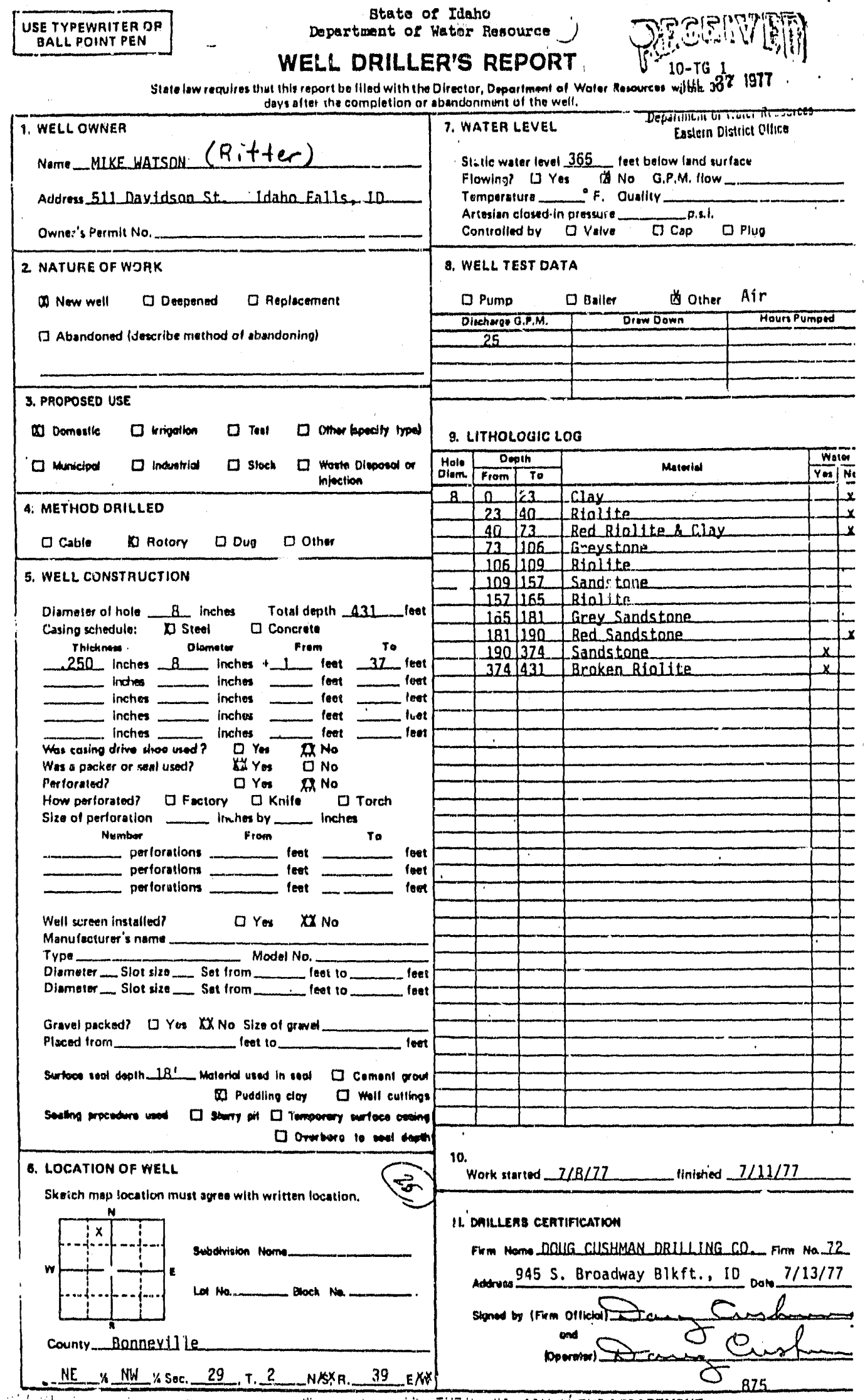




\section{WELL DRILLER'S REPORT}

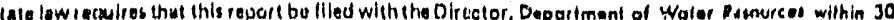
days efler ine completion or atiendorinunt of the vielt.

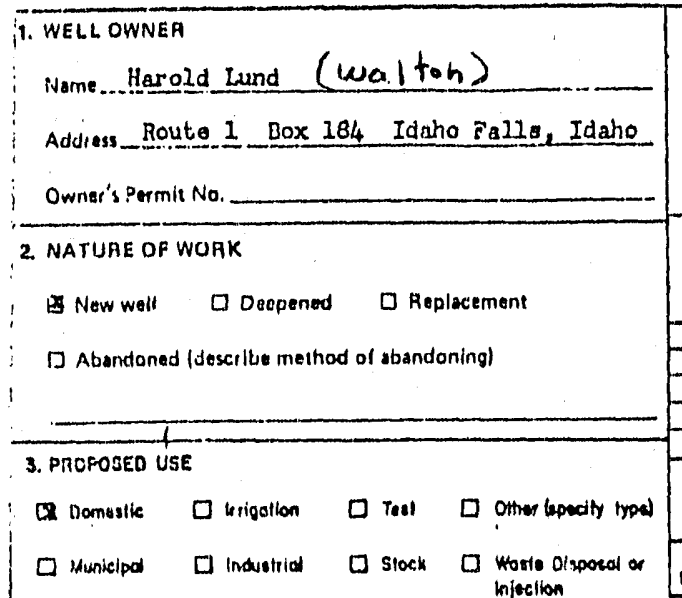

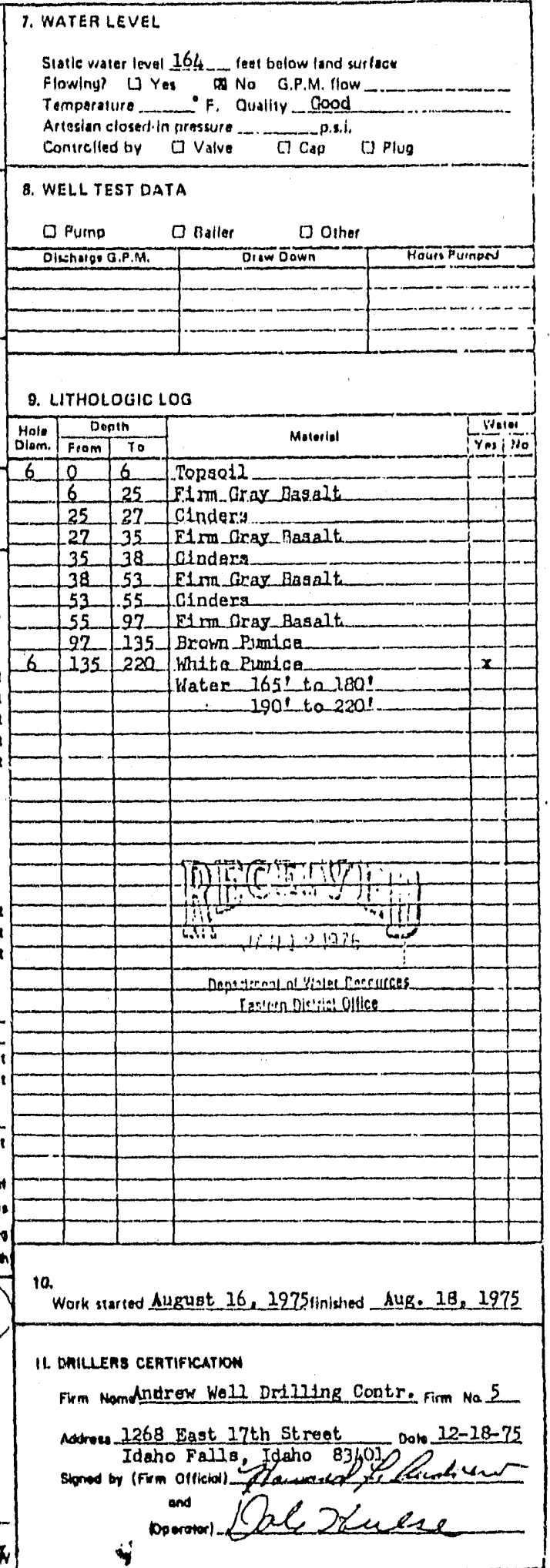

4. METHOD DAILLED

$\square$ Cable 8 Rotory $\square$ Dug $\square$ Other

5. WELL CONSTAUTCTION

Dismeter ul hole 6 inches Total depth 230 _leet Cising schedula: 25 sieal 0 Concrote Thicknass Dlamaler from

- indres $\longrightarrow$ inches

_._ inches ___ inches __ leot

_- inches ___ inches ___ leat

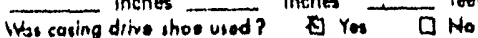

Was a packer or seal used? D Yes BNo

Perforated? $\square$ Yes $D$ No

How perlornied? $\square$ Factory $\square$ Knifo $\square$ Torch

Size of pertoration

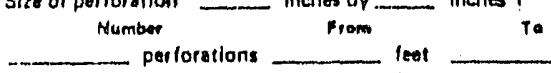
perforatlons

teet

Well screen instalied? $D$ Yos $D$ No

Munulacturur's nam

Type

Diambier — Slot sizo _... Set from

Model No.

Diameter _. Slot slize _ Set from___ leet

Graual packed? $\square$ Yes (X. No Slze of graved

Placed trom___ feet to Bentonito

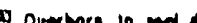

6. LOCATION OF WELL

Skatch map location must agies with written location.

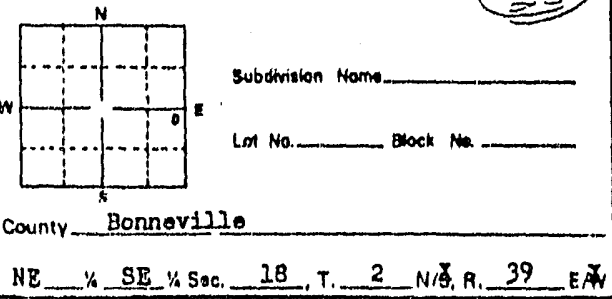

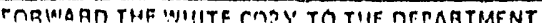


APPENDIX B

FIELD WATER LEVEL DATA 
WATER LEVEL/PUMPING TEST RECORD. PAGE 1 OF 2 \#333140010

PROJECT Camere Soma wELL Ritter SITE 7245 E. Rimrock Drive

SCREEN

SETTING

STATIC 355, below WATER LEVEL

DRAWDOWN XU

RECOVERY

DISTANCE FROM WELL

MEASURED TO PUMPING

WELL (r) NA

\begin{tabular}{|c|c|c|c|}
\hline $\begin{array}{c}\text { DATE \& } \\
\text { TIME }\end{array}$ & $\begin{array}{c}\text { WELL } \\
\text { OR } \\
\text { t(mins) }\end{array}$ & $\begin{array}{c}\text { HELD } \\
\text { (t) }\end{array}$ & $\begin{array}{c}\text { WET } \\
\text { (tt) }\end{array}$ \\
\hline M920 & 0 & & \\
\hline 0923 & 0 & & \\
\hline 0926 & 0 & & \\
\hline
\end{tabular}

$0930.00 \Omega$

$09: 3015.25$

$09: 30: 30.50$

$0950: 45.75$

$0931: 001.0$

$0.31: 301.5$

0:32:00 2.0

0:32:30 2.5

9:30:00 3,0

\$:33:30 3.5

9:34:00 4.0

Q:34:30 4.5

9:35100 5

9:25: 30 5.5

2:36:00 6

$9: 36: 30 \quad 6.5$

9:37:00 7

$9: 37: 30 \quad 7.5$

$9: 38: 008$

q: $38: 30 \quad 80^{\circ}$

$9: 39: 009$

$9: 40: 00 \cdot 10$

$9: 41: 00 \quad 11$

9:42:00 12

RATE
9:43:00 13

MEASURING POINT Top of sted casing HeIGHT ABOVE 17 inchan DESCRIPTION

MEASURED WITH Solinst

START OF TEST 0930

END OF TEST _ $\quad 0950$

DATETIME $8 / 14 / 91$

PUMPING Ritter

WELL

DISCHARGE.

ORIFICE

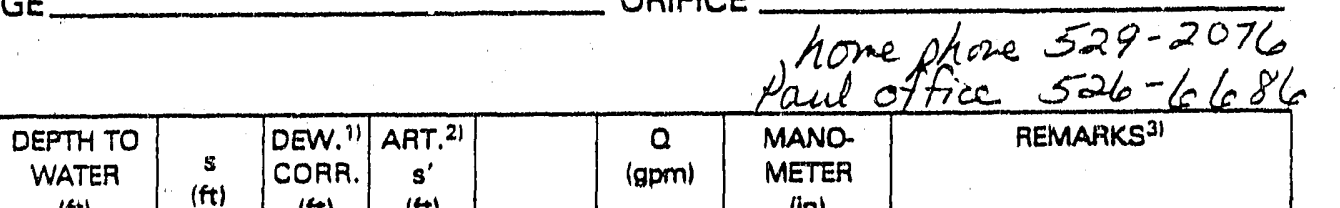

\begin{tabular}{|c|c|c|}
\hline $\begin{array}{c}\text { WATEA } \\
(\mathrm{ft})\end{array}$ & $(\mathrm{ft})$ & $(t+)$. \\
\hline 355,82 & 0 & \\
\hline 355.82 & 0 & \\
\hline 355,82 & 0 & \\
\hline
\end{tabular}

355.820

$355.87 \quad .05$

355.85 .03

355.85 .03

355.85 .03

355.86 .04

$355.85 \quad .03$

355.85 .03

$\$ 55.85 .03$

35.86 .04

355.86 .04

055,86

355.86

355.86

355,86

355.86

355.86

355.86

355.86

355.86

355.86

355.86

355.86

355.86

355.86

\begin{tabular}{|c|c|}
\hline$\underset{(\mathrm{gpm})}{Q}$ & $\begin{array}{l}\text { MANO } \\
\text { METER } \\
\text { (in) }\end{array}$ \\
\hline 0 & \\
\hline 0 & \\
\hline 0 & \\
\hline$L$ & \\
\hline
\end{tabular}

turn on pums

10

10.7

11.5

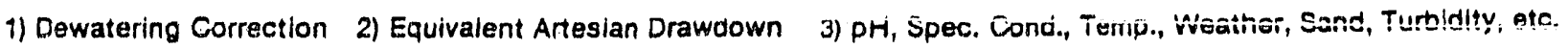


WATER LEVEL/PUMPING TEST RECORD (Cont'd.) . PAGE_2_OF 2

paoject Camale oloma WELL Ritter SITE 7245 \& Rimrock Drive \#33/40010

\begin{tabular}{|c|c|c|c|c|c|c|c|c|c|c|}
\hline \begin{tabular}{l|l|l} 
DATE \& \\
- TIME \\
\end{tabular} & \begin{tabular}{c|} 
WELL \\
OH \\
$t$ (mins)
\end{tabular} & $\begin{array}{c}\text { HEELD } \\
(f t)\end{array}$ & $\begin{array}{c}\text { WET } \\
(f t)\end{array}$ & \begin{tabular}{|c|} 
DEFTH TO \\
WATER \\
$(f \mathrm{t})$
\end{tabular} & $\begin{array}{c}s \\
(t+t)\end{array}$ & \begin{tabular}{|c|} 
EEW. \\
CORR \\
(fts)
\end{tabular} & $\begin{array}{l}\mathrm{ART}^{2{ }^{2}} \\
s^{\prime} \\
\text { (ft) }\end{array}$ & $\underset{\text { (gpm) }}{a}$ & $\begin{array}{c}\text { MANO- } \\
\text { METER } \\
(\text { (m) }\end{array}$ & REMARKS \\
\hline $99,44,00$ & 14 & & & 355,86 & .04 & & & 14.3 & & \\
\hline $09,45.00$ & 15 & & & 355.86 & 1 & & & & & \\
\hline $99: 45: 30$ & 0 15. & & & 355.86 & & & & & & Tyred on taucets in hip \\
\hline $3 \phi i 46: \infty$ & 016 & & & 355.86 & & & & & & \\
\hline $09: 47: 00$ & $\begin{array}{lll}0 & 11 \\
\end{array}$ & & & 355.86 & & & & & & \\
\hline$x 9: 48:$ oc & 018 & & & 355.86 & 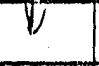 & & & & & \\
\hline & $\square$ & & & ב & -54 & $m$ & & & & \\
\hline $8: 49: 00$ & $0 \quad 19$ & & & 355.86 & & & & & & \\
\hline $20: 50: 00$ & $0 \quad 20$ & $t^{\prime \prime}$ & & 355.86 & .04 & & & & & Shut eff water \\
\hline $29: 50: 30$ & $2 \quad 20.7$ & 0 & & 355.86 & .04 & & & & $\lambda$ & piupsutoll \\
\hline $39: 50.45$ & 20.75 & 1512 & & 355.84 & .02 & & & & & \\
\hline $39: 51: 00$ & 21 & 30 sh & & 355.84 & .02 & & & & & \\
\hline $9: 51: 15$ & $21,2 \mathrm{P}$ & $1: 15$ & & 355.83 & .01 & & & & & recovery \\
\hline $29: 51: 30$ & 21.5 & $1: 30$ & & 255.83 & .01 & & & & & if \\
\hline $99: 52: 00$ & 22 & $2: 00$ & & 355.83 & .01 & & & & & \\
\hline $99: 53: 00$ & $0 \quad 23$ & $2: 30$ & & 355.82 & .00 & & & & V & \\
\hline
\end{tabular}

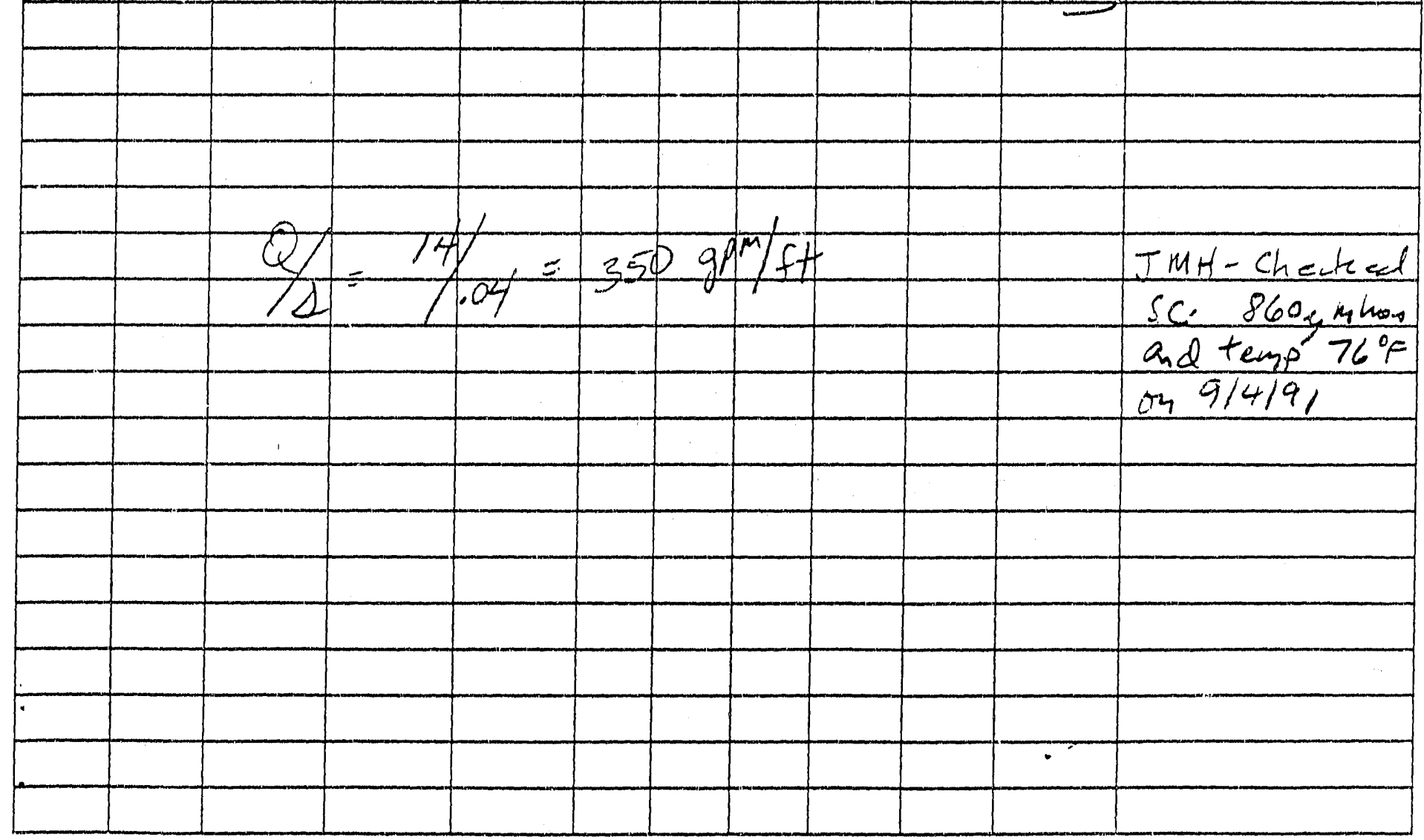

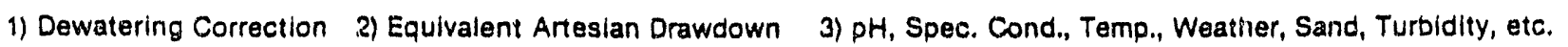


owner John Watton Address County Eonnel ilestate I D Date $8 / 29 / 91$ company pertorming test $E G \neq G$ Measurea by J.M Habbell

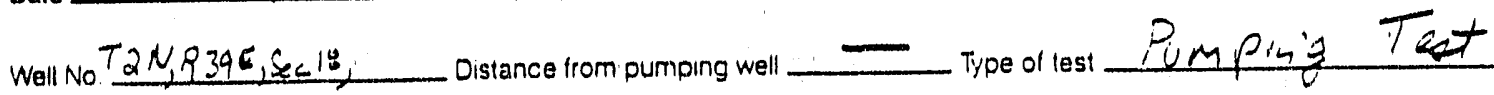
Test No Measuring equipment Solin:t

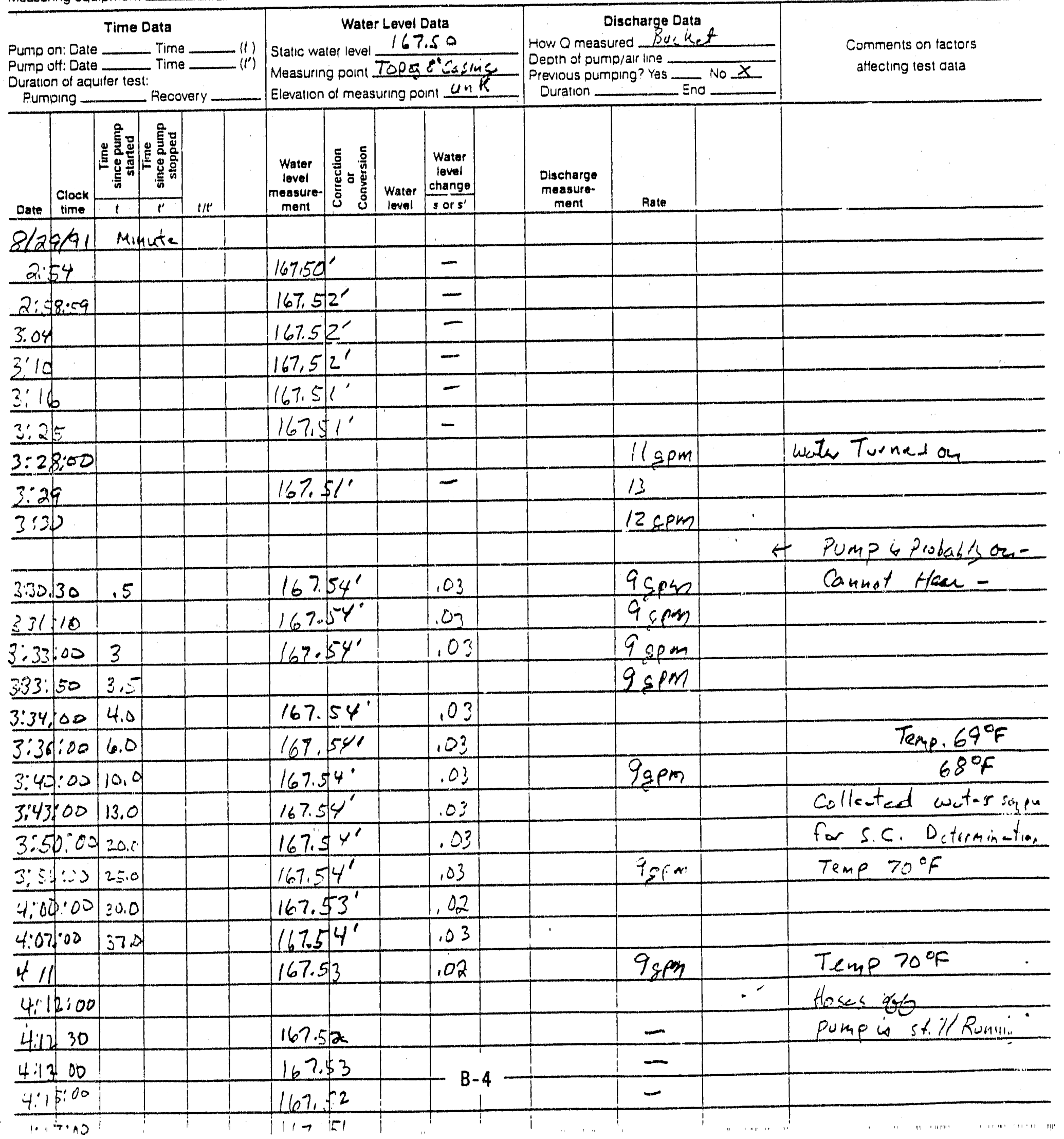


rago 2 of 2

\section{AQUIFER TEST DATA}

Owner Jonn isalto in

Date $8 / 26 / 91$ Company pertorming test E6+6

Souniy Stale

Well No.

Distance from pumping well

Type of lest

Test No.

Méasuring equidinent

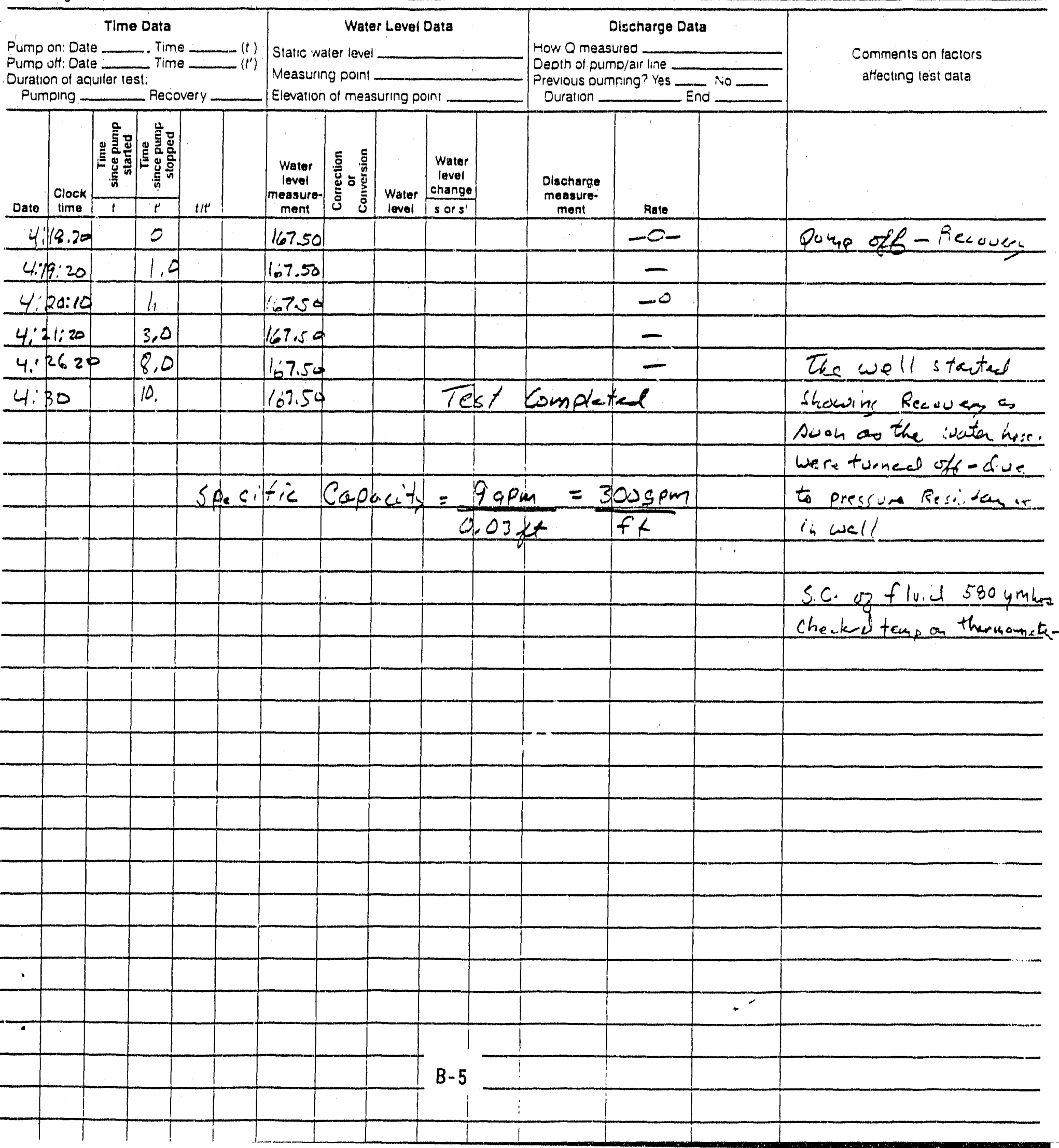



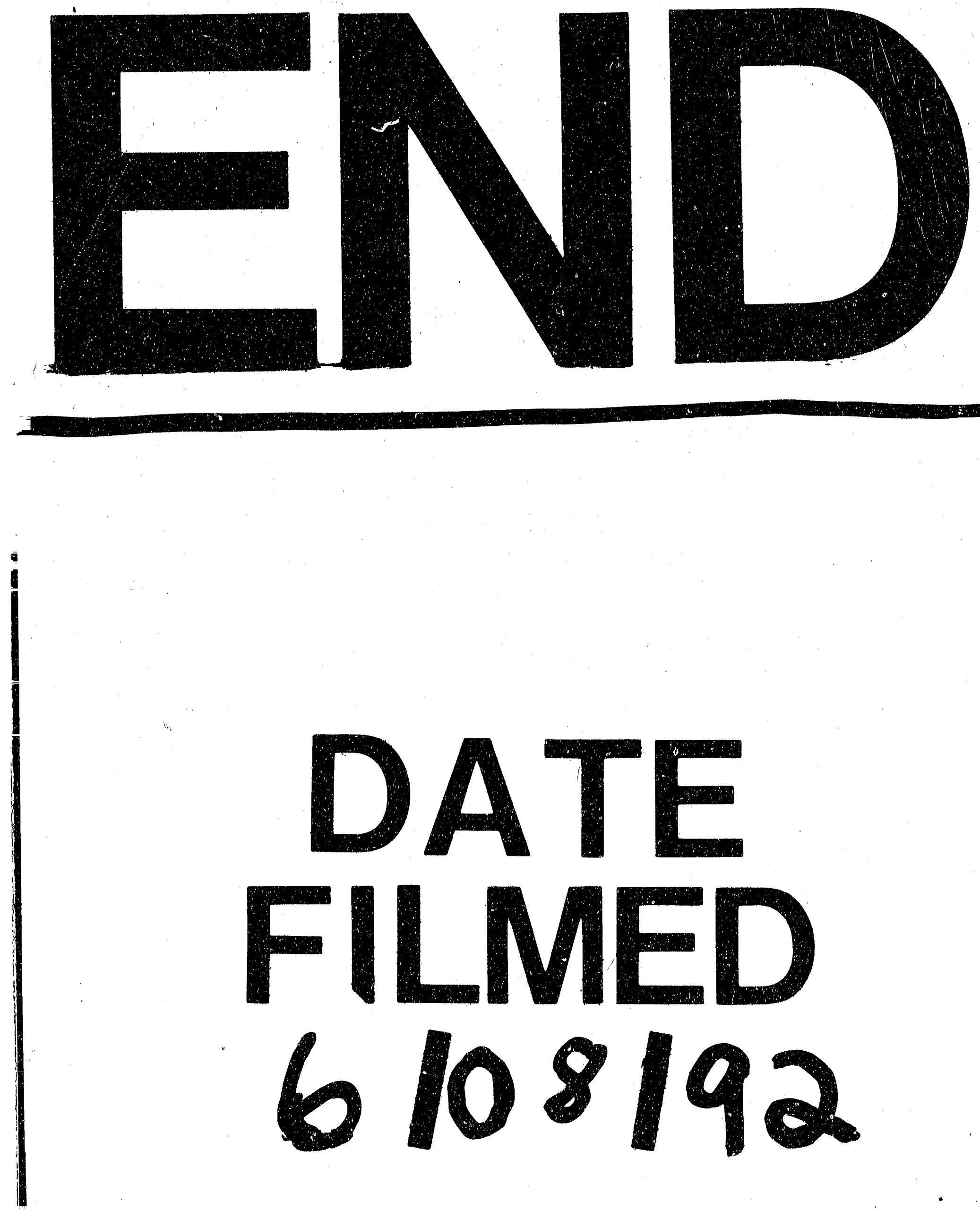
